\title{
Hair whitening and obesity are independently related to ascending aorta dilatation in young-middle aged men
}

\author{
(1) Mustafa Cetin, ${ }^{1}$ (1) Emrah Bozbeyoglu, ${ }^{2}$ (1) Turan Erdogan, ${ }^{1}$ (1) Sinan Altan Kocaman, ${ }^{3}$ \\ (D) Omer Satiroglu, ${ }^{1}$ (D) Murtaza Emre Durakoglugil ${ }^{1}$ \\ ${ }^{1}$ Department of Cardiology, Recep Tayyip Erdogan University Faculty of Medicine, Rize, Turkey \\ ${ }^{2}$ Department of Cardiology, Dr. Siyami Ersek Thoracic and Cardiovascular Surgery Training and Research Hospital, Istanbul, Turkey \\ ${ }^{3}$ Department of Cardiology, Ankara Guven Hospital, Ankara, Turkey
}

\begin{abstract}
OBJECTIVE: Hair whitening (HW) is strongly linked with aging. Ascending aortic dilation (AAD) and HW share common etiologic factors. We investigated the association of $\mathrm{HW}$ with ascending aortic diameters.

METHODS: Our study included 93 male subjects aged below 50 years. All patients underwent echocardiography to measure ascending aortic diameter, in addition to routine biochemistry tests, physical examination, and thorough medical history. HW score (HWS) was defined according to the percentage of white hair (HWS 1: <25\%; HWS 2: 25-50\%; HWS 3: 50-75\%; and HWS 4: 75-100).

RESULTS: Patients with highest HWS were older and had a higher percentage of hypertension (HT) and family history of HW. Moreover, this subgroup had increased ascending aortic diameter, higher serum uric acid, and lower total bilirubin concentrations. Multivariate analyses including age, HT, height, waist circumference, c-reactive protein, and family history of HW identified body weight and HWS as the independent predictors of ascending aortic diameter.

CONCLUSION: An independent association between the degree of HW and AAD exists in middle-aged men, which may depend on coexisting factors that enhance both pathologies rather than causality. We think that oxidative stress may be one of these stressors.

Keywords: Ascending aorta dilatation; hair graying; Hair whitening; men; obesity; oxidative stress.

Cite this article as: Cetin M, Bozbeyoglu E, Erdogan T, Kocaman SA, Satiroglu O, Durakoglugil ME. Hair whitening and obesity are independently related to ascending aorta dilatation in young-middle aged men. North Clin Istanb 2019;6(1):33-39.
\end{abstract}

$\mathrm{H}^{2}$ air whitening (HW), a frequently encountered situation related in elderly, is strongly linked with aging. Higher oxidative stress and lower antioxidant capacity in addition to aging may be the most important factor for HW [1]. Other factors that may cause HW besides oxidative stress are a family history of HW, smoking, obesity, inflammatory conditions, androgen use, and social stress [2-8].
Interestingly, risk factors for premature $\mathrm{HW}$ (PHW) including obesity, smoking, aging, inflammatory conditions, and oxidative stress also have major roles in cardiovascular diseases mainly atherosclerotic process [9-11]. Intrigued by these results, several investigators and we have demonstrated the association of, especially, PHW with endothelial dysfunction, the extent of coronary artery disease (CAD), and myocardial infarction

Received: September 11, 2017 Accepted: November 08, 2017 Online: August 07, 2018

Correspondence: Dr. Mustafa CETIN. Recep Tayyip Erdogan Universitesi Tip Fakultesi, Kadiyoloji Anabilim Dali, Rize, Turkey.

Tel: +90 4642123009 e-mail: dr.mustafacetin@hotmail.com

(c) Copyright 2019 by Istanbul Provincial Directorate of Health - Available online at www.northclinist.com 
[12-16]. Christoffersen et al. [16] demonstrated that although affected by atherosclerotic risk factors, HW was not an independent predictor of CAD in an epidemiologic study. However, HW remained significantly associated with myocardial infarction after adjusting for age and gender. This study revealed that, even if individuals were within similar age groups, the intensity of $\mathrm{HW}$ was related to atherosclerosis.

Although these studies have mainly focused on the relation of $\mathrm{HW}$ with atherosclerotic diseases, there is a reasonable possibility that $\mathrm{HW}$ may be associated with different cardiovascular pathologies, which in fact may be affected by oxidative stress, the most important mediator of HW. Ascending aortic dilation (AAD) is such a disorder $[17,18]$. AAD is a clinical entity based on cystic medial degeneration/necrosis, which culminates in acute and deadly complications such as aortic dissection and rupture. Besides congenital reasons, age, smoking, and atherosclerosis are associated with AAD [19, $20]$. We have previously demonstrated that epicardial adipose tissue and endothelial dysfunction are independently related with AAD $[21,22]$. Since AAD and HW share common etiologic factors, we thought that these pathologies might be related as well. We planned to investigate this association in our study.

\section{MATERIALS AND METHODS}

Patient selection and study protocol

Our study, having cross-sectional and observational design, included 93 male subjects aged below 50 years. The study was conducted in accordance with the principles stated in the Declaration of Helsinki and was approved by the local Ethics Committee. All patients underwent echocardiography to measure ascending aortic diameter, routine biochemistry tests, and physical examination in addition to thorough medical history.

We excluded patients with concomitant cardiovascular disease, familial aortic dilation, Marfan syndrome, bicuspid aortic valve, Ehlers-Danlos syndrome and similar connective disease disorders, malignancy, chronic renal and hepatic failure, obstructive biliary disorders, and HW due to autoimmune diseases and patients who dye hair or who has excessive balding that precludes correct identification of $\mathrm{HW}$.

Baseline characteristics of the patient were recorded. Hypertension (HT) was defined as the active use of antihypertensive drugs or documentation of blood pres- sure $>140 / 90 \mathrm{mmHg}$. Diabetes mellitus was defined as fasting plasma glucose levels over $126 \mathrm{mg} / \mathrm{dl}$ or glucose level over $200 \mathrm{mg} / \mathrm{dl}$ at any measurement or active use of antidiabetic treatment. Patients who were using tobacco products on admission and those quitted smoking within the past year were considered as smokers. The family history for CAD was defined as a history of CAD or sudden death in a first-degree relative before the age of 55 years in men and 65 years in women.

\section{Routine measurements}

Blood samples were drawn by venipuncture to measure routine blood chemistry parameters after fasting for at least 8 h. Fasting blood glucose, serum creatinine, total cholesterol, high-density lipoprotein cholesterol, lowdensity lipoprotein cholesterol, and triglyceride levels were recorded. Glucose, creatinine, and lipid profile were determined by standard methods. Serum c-reactive protein $(\mathrm{CRP})$ was analyzed using a nephelometric technique (Beckman Coulter Immage 800; Fullerton, CA, USA; normal range $0-0.8 \mathrm{mg} / \mathrm{dL}$ ). Serum uric acid levels were evaluated using enzymatic colorimetric method (the uricase-peroxidase method) by clinical chemistry auto-analyzer (Aeroset, Abbott Laboratory, Abbott Park, IL, USA). Body mass index (BMI) was determined by the following formula: BMI=weight $(\mathrm{kg}) /$ height $^{2}(\mathrm{~m})$.

\section{Measurement of ascending aortic diameter}

Transthoracic echocardiography was performed using GE-Vingmed Vivid S5 (GE-Vingmed Ultrasound AS, Horten, Norway) using a $2.5-3.5 \mathrm{MHz}$ transducer. Parasternal long-axis view was used to visualize the aortic root and proximal ascending aorta. The aortic diameter was measured between the inner edges of the aortic lumen perpendicular to the long axis $2 \mathrm{~cm}$ above the sinotubular junction at end-diastole in views showing the largest aortic diameters.

\section{The evaluation of hair whitening intensity}

We used a gray/white-hair scale to determine the percentage of HW (Fig. 1). Due to the lack of a standardized scale to determine PHW in the current literature, we assessed this scale for reproducibility in the first 25 subjects. Two experienced cardiologists who were totally blinded to the study details defined the percentage of white hair in every subject using this scale (between $0 \%$ and $100 \%$ ) in our outpatient clinic. The intra- and 


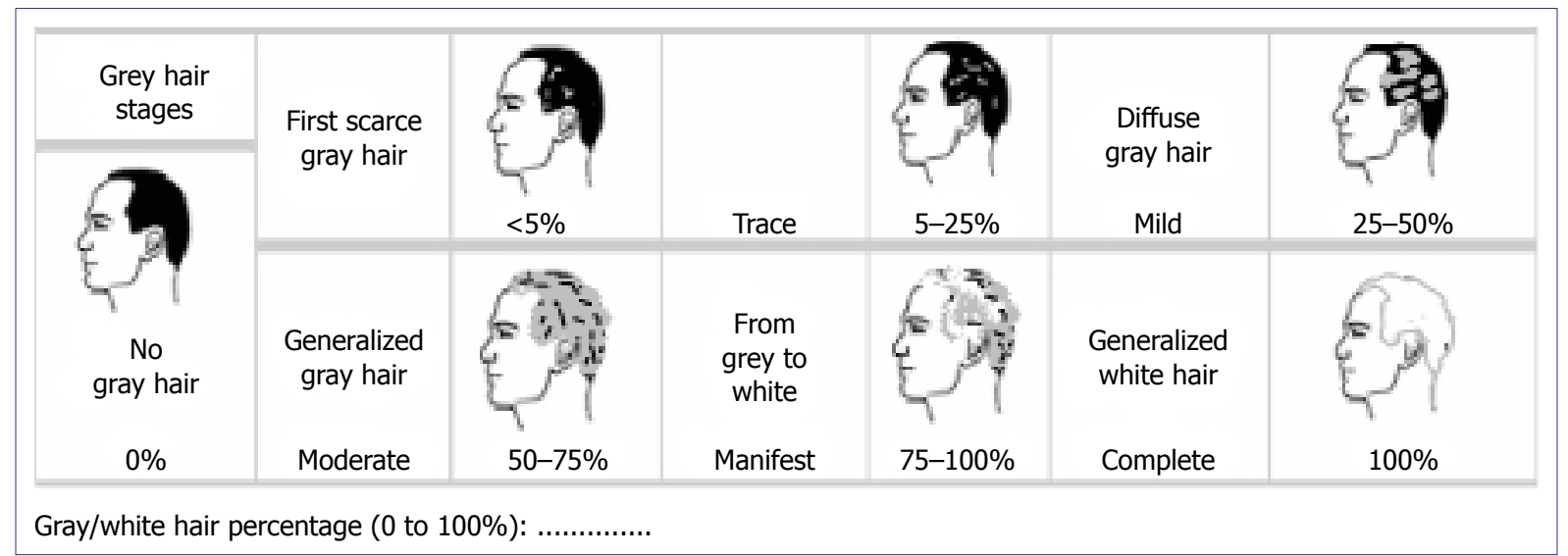

FIGURE 1. The gray/white hair scale

inter-observer variabilities for this method were $1.3 \%$ and $1.9 \%$, respectively. On presentation, to categorize the data, the HW score (HWS) was defined according to the percentage of white hair (HWS 1 [trace]: $<25 \%$; HWS 2 [mild]: 25-50\%; HWS 3 [moderate]: 50-75\%; HWS 4 [manifest]: 75-100\%; and HWS 5 [complete]: $100 \%)$. Onset age of HW and family history of early $\mathrm{HW}$ were also determined.

\section{Statistical analyses}

Continuous variables were given as mean \pm standard deviation; categorical variables were defined as percentages. Data were tested for normal distribution using the Kolmogorov-Smirnov test. Spearman's rank correlation coefficient was used to analyze the relationship between the variables. Mean values were compared by ANOVA test among different groups. Multiple linear regression analyses were used to assess multivariate relations among ascending aortic diameter and HW degree and study parameters. In these analyses, a stepwise method for all independent variables was used. After first pre-elimination, linear regression analysis with Enter method was repeated.

Statistical significance was defined as $\mathrm{p}<0.05$. All tests of significance were two-tailed. The SPSS statistical software (SPSS for Windows, version 15.0, Inc., Chicago, IL, USA) was used for all statistical calculations.

\section{RESULTS}

\section{Patient characteristics}

Baseline characteristics of the group are presented in Table 1. Our study included 93 male subjects with the
TABLE 1. Baseline demographics and clinical characteristics of study population

Variables

Patients $(n=93)$

Age, years

$44 \pm 6$

Height, $\mathrm{m}$

$1.7 \pm 0.1$

Weight, kg

$88.5 \pm 12.9$

Waist circumference, $\mathrm{cm}$

$102 \pm 12$

Hypertension, \%

23.7

Diabetes Mellitus, \%

5.4

Smoking status, \%

41.9

Ex-smoker, \%

37.7

Dyslipidemia, \%

43

Family history of CAD, \%

29

HW age, years

$29 \pm 10$

Family history of HW

$17.6 \%$

Glucose, mg/dL

$98 \pm 26$

Creatinine, $\mathrm{mg} / \mathrm{dL}$

$0.89 \pm 0.12$

Uric acid, mg/dL

$5.6 \pm 1.2$

T. Bilirubin, $\mathrm{mg} / \mathrm{dL}$

$0.92 \pm 0.51$

Total cholesterol, $\mathrm{mg} / \mathrm{dL}$

$205 \pm 42$

LDL-Cholesterol, $\mathrm{mg} / \mathrm{dL}$

$128 \pm 34$

HDL-Cholesterol, mg/dL

$41 \pm 9$

Triglycerides, mg/dL

$176 \pm 102$

CRP,mg/dL,

$0.42 \pm 0.50$

Leukocytes, 103/mm³

$7.7 \pm 1.6$

Ascending aortic diameter, $\mathrm{mm}$

$34 \pm 4$

Percentage of HW

$47 \pm 39$

HW score (1-5)

$2.4 \pm 1.3$

CAD: Coronary artery disease; CRP: C-reactive protein; HDL: High density lipoprotein; HW: hair whitening; LDL: Low density lipoprotein; Continuous variables were given as mean $\pm \mathrm{SD}$; categorical variables were defined as percentages. 
mean age of $44 \pm 6$. Starting age of $H W$ was $29 \pm 10$, and approximately $18 \%$ of patients confirmed a family history of HW. Percentage of HW was variable (47 \pm 39$)$ with a mean HWS of $2.4 \pm 1.3$.

Hair whitening and study parameters

As we stratified the group according to quartiles of HW, patients with the highest degree of $\mathrm{HW}$ were older and had a higher percentage of HT and family history of HW (Table 2). Moreover, this subgroup had increased ascending aortic diameter, higher serum uric acid, and lower total bilirubin concentrations.

Correlations of ascending aortic diameter with study parameters

The strongest association existed between ascending aor- tic diameter and percentage of HW $(r \div 0.513, p<0.001)$ (Table 3). Age, body weight, waist circumference, serum uric acid, and CRP concentrations were positively correlated, whereas HW age and total bilirubin concentrations were negatively correlated with ascending aortic diameter. The correlations between ascending aortic diameter and HW percentage were moderate; however, the remaining correlations were weak.

\section{Multivariate analyses}

Multivariate analyses including age, HT, height, waist circumference, CRP, and family history of HW identified body weight $(\beta \pm$ standard error $[S E]=0.09 \pm 0.03$, $\mathrm{p}=0.001)$ and HWS $(\beta \pm \mathrm{SE}=1.35 \pm 0.27, \mathrm{p}<0.001)$ as the independent predictors of ascending aortic diameter (Table 4).

TABLE 2. The relation between hair whitening degree and study parameters

\begin{tabular}{|c|c|c|c|c|c|}
\hline $\begin{array}{l}\text { Variables } \\
\text { n (93) }\end{array}$ & $\begin{array}{c}0-25 \% \\
(36)\end{array}$ & $\begin{array}{c}25-50 \% \\
(16)\end{array}$ & $\begin{array}{c}50-75 \% \\
(12)\end{array}$ & $\begin{array}{c}75-100 \% \\
(29)\end{array}$ & $\mathrm{p}$ \\
\hline Age, years & $42 \pm 5$ & $43 \pm 5$ & $46 \pm 5$ & $48 \pm 5$ & $<0.001$ \\
\hline Diabetes Mellitus, \% & 5.5 & 6.2 & 8.3 & $3 \%$ & NS \\
\hline Hypertension, \% & 8.3 & 18.6 & 33.3 & 41.4 & 0.014 \\
\hline Dyslipidemia, \% & 44.4 & 37.5 & 50 & 41.4 & NS \\
\hline Smoking, \% & 38.8 & 50 & 50 & 37.9 & NS \\
\hline Ex-smoker, \% & 29.2 & 30 & 50 & 47.6 & NS \\
\hline Family history of premature CAD & 22.2 & 50 & 33.3 & 24.1 & NS \\
\hline Height, m & $1.75 \pm 0.06$ & $1.72 \pm 0.075$ & $1.76 \pm 0.076$ & $1.75 \pm 0.068$ & NS \\
\hline Weight, kg & $86 \pm 11$ & $85 \pm 15$ & $88 \pm 12$ & $94 \pm 14$ & 0.09 \\
\hline Waist circumference, $\mathrm{cm}$ & $99 \pm 15$ & $99 \pm 15$ & $104 \pm 11$ & $105 \pm 13$ & NS \\
\hline HW age, years & $23 \pm 20$ & $34 \pm 3$ & $32 \pm 4$ & $27 \pm 7$ & 0.01 \\
\hline Family history of HW & $0 \%$ & $0 \%$ & $0 \%$ & $55 \%$ & $<0.001$ \\
\hline Glucose, mg/dL & $101 \pm 36$ & $97 \pm 11$ & $86 \pm 7$ & $100 \pm 18$ & NS \\
\hline Creatinine $\mathrm{mg} / \mathrm{dL}$ & $0.89 \pm 0.14$ & $0.91 \pm 0.13$ & $0.86 \pm 0.10$ & $0.89 \pm 0.11$ & NS \\
\hline Uric acid, mg/dL & $5.3 \pm 1.2$ & $5.2 \pm 1.2$ & $5.3 \pm 0.9$ & $6.1 \pm 1.4$ & 0.043 \\
\hline Total bilirubin, $\mathrm{mg} / \mathrm{dL}$ & $1.01 \pm 0.57$ & $1.19 \pm 0.65$ & $0.71 \pm 0.24$ & $0.75 \pm 0.35$ & 0.027 \\
\hline Total cholesterol, $\mathrm{mg} / \mathrm{dL}$ & $202 \pm 46$ & $207 \pm 32$ & $203 \pm 42$ & $209 \pm 43$ & NS \\
\hline $\mathrm{HDL}-\mathrm{C}, \mathrm{mg} / \mathrm{dL}$ & $42 \pm 11$ & $40 \pm 6$ & $42 \pm 5$ & $39 \pm 7$ & NS \\
\hline LDL-C, mg/dL & $124 \pm 37$ & $128 \pm 23$ & $128 \pm 35$ & $133 \pm 36$ & NS \\
\hline Triglycerides, mg/dL & $168 \pm 86$ & $199 \pm 103$ & $169 \pm 89$ & $178 \pm 123$ & NS \\
\hline $\mathrm{CRP}, \mathrm{mg} / \mathrm{dL}$ & $0.25 \pm 0.15$ & $0.30 \pm 0.15$ & $0.89 \pm 1.20$ & $0.49 \pm 0.24$ & 0.001 \\
\hline Leukocytes, $10^{3} / \mathrm{mm}^{3}$ & $7.60 \pm 1.36$ & $7.67 \pm 1.37$ & $8.13 \pm 2.25$ & $7.74 \pm 1.63$ & NS \\
\hline Ascending aortic diameter, $\mathrm{mm}$ & $32.8 \pm 3.34$ & $32.4 \pm 2.96$ & $34.5 \pm 3.68$ & $36.8 \pm 3.2$ & $<0.001$ \\
\hline
\end{tabular}

CAD: Coronary artery disease; CRP: C-reactive protein; HDL: High density lipoprotein; HW: hair whitening; LDL: Low density lipoprotein; Continuous variables were given as mean $\pm \mathrm{SD}$; categorical variables were defined as percentages. *Mean values were compared by ANOVA test among different groups. 
TABLE 3. The correlations between ascending aortic diameter and study parameters

\begin{tabular}{lc} 
Variables, $\mathrm{n}(93)$ & Ascending aortic diameter \\
\hline Hair whitening score & $\mathrm{r}=0.504, \mathrm{p}<0.001$ \\
Percentage of HW & $\mathrm{r}=0.513, \mathrm{p}<0.001$ \\
HW age, years & $\mathrm{r}=-0.275, \mathrm{p}=0.025$ \\
Age, years & $\mathrm{r}=0.371, \mathrm{p}=0.001$ \\
Height, $\mathrm{m}$ & $\mathrm{r}=0.261, \mathrm{p}=0.012$ \\
Weight, kg & $\mathrm{r}=0.386, \mathrm{p}<0.001$ \\
Waist circumference, cm & $\mathrm{r}=0.275, \mathrm{p}=0.022$ \\
Uric acid, mg/dL & $r=0.278, \mathrm{p}=0.008$ \\
CRP, mg/dL & $r=0.325, \mathrm{p}=0.002$ \\
Total bilirubin, mg/dL & $r=-0.097, \mathrm{p}=0.388$ \\
\hline
\end{tabular}

CRP: C-reactive protein; HW: hair whitening; Spearman's rank correlation coefficient was used to analyze the relationship between the variables.

\section{DISCUSSION}

We revealed that $A A D$ was significantly associated with HW and obesity. The relationship between AAD and HW is novel. We hypothesize that this association is not causal, which might exist mainly due to co-existing etiologic factors and parallel pathogenic processes.
Oxidative stress might be major etiologic agent in this parallel process. Even though neither of our laboratory values did not correlate with oxidative stress directly, bilirubin known with antioxidant properties had an inverse relationship with HW [23]. Moreover, an oxidative stress product in ischemic conditions, serum uric acid concentration was related to ascending aortic diameter [24]. We observed a similar association between HW and serum uric acid. In addition, CRP, an inflammatory marker, was correlated to both HW and aortic dilation. This result was concurrent with previous studies that support the inflammatory hypothesis regarding HW [16]. Even though our results may not directly link HW and aortic dilation to oxidative stress, data support our hypothesis.

Aging is a natural course indubitably related to higher oxidative stress $[16,25]$. The imbalance between increased oxidant molecules and decreased antioxidant factors causes accumulation of free radicals. These radicals affect cellular membrane, lipids, DNA, proteins, and crucial enzymes. Melanocytes might be influenced by oxidative stress, which in turn disturb melanocyte function and melanin synthesis. This is the currently accepted mechanism of HW.

Aortic aneurysm is an inflammatory disorder char-

TABLE 4. The independent association of ascending aortic diameter with study parameters

Linear regression analysis

Independent variables

\begin{tabular}{|c|c|c|c|c|c|}
\hline$p$ & $\begin{array}{c}\text { Beta } \\
\text { (Standardized) }\end{array}$ & $\begin{array}{c}\text { Beta } \pm \text { SE } \\
\text { (Unstandardized } \\
\text { Coefficients) }\end{array}$ & $\mathrm{p}$ & $\begin{array}{c}\text { Beta } \\
\text { (Standardized) }\end{array}$ & $\begin{array}{c}\text { Beta } \pm \text { SE } \\
\text { (Unstandardized } \\
\text { Coefficients) }\end{array}$ \\
\hline
\end{tabular}

\begin{tabular}{|c|c|c|c|c|c|c|}
\hline Age, years & 0.337 & 0.111 & $0.07 \pm 0.07$ & & & \\
\hline Hypertension & 0.420 & 0.089 & $0.72 \pm 0.88$ & & & \\
\hline Height, m & 0.758 & -0.040 & $-2.50 \pm 8.08$ & & & \\
\hline Waist circumference, cm & 0.223 & -0.333 & $-0.10 \pm 0.08$ & & & \\
\hline Uric acid, mg/dL & 0.313 & 0.110 & $0.30 \pm 0.29$ & & & \\
\hline HW score & 0.001 & 0.413 & $1.12 \pm 0.32$ & $<0.001$ & 0.501 & $1.35 \pm 0.27$ \\
\hline Constant & 0.061 & & $27 \pm 14$ & $<0.001$ & & $23 \pm 2.2$ \\
\hline Adjusted $\mathrm{R}^{2}$ & 0.426 & 0.442 & & & & \\
\hline
\end{tabular}

SE: standard error; CRP: C-reactive protein; HW: hair whitening; Multiple linear regression analyses were used to assess multivariate relations among ascending aortic diameter and hair whitening degree and study parameters. 
acterized by weakening of aortic wall and ensuing aortic dilation due to increased turnover of connective tissue. Although the mechanism is not completely understood, hemodynamic stress on aortic wall, transmural inflammation, and destructive remodeling of the extracellular matrix have been plausibly blamed [26-29]. Inflammatory mediators augment matrix metalloproteinase (MMP) activity, which causes disruption of extracellular matrix and subsequent remodeling of the aortic wall [30-33]. Since reactive oxygen species enhance MMPs, oxidative stress, in addition to inflammation, has a possible role in the pathogenesis of aortic aneurysms [34]. Ejiri et al. [17] demonstrated higher oxidative stress in patients with thoracic aortic aneurysm compared to controls, which was associated with $\mathrm{p} 22$ phox-based nicotinamide adenine dinucleotide/nicotinamide adenine dinucleotide phosphate oxidase expression. Another study demonstrated decreased basal and oxidative stress-induced metallothionein expression in ascending aortic aneurysms of bicuspid aortic valve patients [35]. Since metallothionein is a stress-induced metal binding protein that regulates MMP activity and is upregulated under oxidative stress, this study demonstrated the importance of imbalance between oxidant and antioxidant molecules in the pathogenesis of aortic aneurysm.

Another independent predictor of our study is body weight. Body weight determines obesity, and obesity is associated with increased visceral, perivascular, and epicardial adipose tissue. We previously demonstrated the relationship of epicardial adipose tissue with AAD [22].

Aortic dilation and aneurysm are an important disorder that might cause death due to aortic dissection and rupture. Since clinical symptoms and signs are scarce, diagnosis is usually incidental. Therefore, clues that suggest aortic dilation may be helpful for diagnosis in the early phase of this condition. Even though early diagnosis is important, there are not viable options to delay or stop further aortic dilation possibly because the mechanisms of aortic dilation are not fully elucidated. The demonstrated association between HW and aortic dilation may add valuable data and help to understand the mechanisms of both HW and aortic dilation.

\section{Study limitations}

Our study has several limitations, the most important of which is the small number of subjects. Our study is observational in design; therefore, our results do not implicate causality. Not utilizing better predictors of total oxidative stress is also a major limitation, making the proposed coexisting factors more speculative. There is not a standardized method for grading of HW. A more standardized method rather than visual grading could have strengthened our results.

\section{Conclusion}

There is an independent association between the degree of $\mathrm{HW}$ and AAD in young-middle aged men, which may depend on coexisting factors that enhance both pathologies rather than causality. We think that oxidative stress may be one of these stressors.

\section{Conflict of Interest: The authors declare no conflict of interest.}

Financial Disclosure: The authors declared that this study has received no financial support.

Authorship Contributions: Concept - M.C., S.A.K.; Design - E.B., T.E.; Supervision - O.S., M.E.D.; Materials - S.A.K., O.S.; Data collection \&/or processing - T.E., M.C.; Analysis and/or interpretation - S.A.K., E.B.; Writing - M.C., E.D.; Critical review - M.C., E.B., T.E., S.A.K., O.S., M.E.D.

\section{REFERENCES}

1. Trüeb RM. Oxidative stress in ageing of hair. Int J Trichology 2009;1:6-14. [CrossRef]

2. Van Neste D, Tobin DJ. Hair cycle and hair pigmentation: Dynamic interactions and changes associated with aging. Micron 2004;35:193200. [CrossRef]

3. Shin H, Ryu HH, Yoon J, Jo S, Jang S, Choi M, et al. Association of premature hair graying with family history, smoking, and obesity: A cross-sectional study. J Am Acad Dermatol 2015;72:321-7. [CrossRef]

4. Tobin DJ, Paus R. Graying: Gerontobiology of the hair follicle pigmentary unit. Exp Gerontol 2001;36:29-54. [CrossRef]

5. Kauser S, Thody AJ, Schallreuter KU, Gummer CL, Tobin DJ. A fully functional proopiomelanocortin/melanocortin-1 receptor system regulates the differentiation of human scalp hair follicle melanocytes. Endocrinology 2005;146:532-43. [CrossRef]

6. Slominski A, Tobin DJ, Shibahara S, Wortsman J. Melanin pigmentation in mammalian skin and its hormonal regulation. Physiol Rev 2004;84:1155-228. [CrossRef]

7. Lindner G, Botchkarev VA, Botchkareva NV, Ling G, van der Veen C, Paus R, et al. Analysis of apoptosis during hair follicle regression (catagen) Am J Pathol 1997;151:1601-17.

8. Mecklenburg L, Tobin DJ, Müller-Röver S, Handjiski B, Wendt G, Peters EM, et al. Active hair growth (anagen) is associated with angiogenesis. J Invest Dermatol 2000;114:909-16. [CrossRef]

9. Wilson PW, D’Agostino RB, Levy D, Belanger AM, Silbershatz H, Kannel WB, et al. Prediction of coronary heart disease using risk factor categories. Circulation 1998;97:1837-47. [CrossRef]

10. Bonomini F, Tengattini S, Fabiano A, Bianchi R, Rezzani R. Atherosclerosis and oxidative stress. Histol Histopathol 2008;23:381-90.

11. Sherer Y, Shoenfeld Y. Mechanisms of disease: Atherosclerosis in autoimmune diseases. Nat Clin Pract Rheumatol 2006;2:99-106. 
12. Erdoğan T, Kocaman SA, Çetin M, Durakoğlugil ME, Uğurlu Y, Şahin $\dot{I}$, et al. Premature hair whitening is an independent predictor of carotid intima-media thickness in young and middle-aged men. Intern Med 2013;52:29-36. [CrossRef]

13. Kocaman SA, Çetin M, Durakoğlugil ME, Erdoğan T, Çanga A, Çiçek $\mathrm{Y}$, et al. The degree of premature hair graying as an independent risk marker for coronary artery disease: A predictor of biological age rather than chronological age. Anadolu Kardiyol Derg 2012;12:457-63.

14. Schnohr P, Lange P, Nyboe J, Appleyard M, Jensen G. Gray hair, baldness, and wrinkles in relation to myocardial infarction: The copenhagen city heart study. Am Heart J 1995;130:1003-10. [CrossRef]

15. Mirić D, Fabijanić D, Giunio L, Eterović D, Culić V, Bozić I, et al. Dermatological indicators of coronary risk: A case-control study. Int J Cardiol 1998;67:251-5. [CrossRef]

16. Christoffersen M, Frikke-Schmidt R, Schnohr P, Jensen GB, Nordestgaard BG, Tybjaerg-Hansen A. Visible age-related signs and risk of ischemic heart disease in the general population: A prospective cohort study. Circulation 2014;129:990-8. [CrossRef]

17. Ejiri J, Inoue N, Tsukube T, Munezane T, Hino Y, Kobayashi S, et al. Oxidative stress in the pathogenesis of thoracic aortic aneurysm: Protective role of statin and angiotensin II type 1 receptor blocker. Cardiovasc Res 2003;59:988-96. [CrossRef]

18. Branchetti E, Poggio P, Sainger R, Shang E, Grau JB, Jackson BM, et al. Oxidative stress modulates vascular smooth muscle cell phenotype via CTGF in thoracic aortic aneurysm. Cardiovasc Res 2013;100:316-24.

19. Isselbacher EM. Thoracic and abdominal aortic aneurysms. Circulation 2005;111:816-28. [CrossRef]

20. Carlson RG, Lillehei CW, Edwards JE. Cystic medial necrosis of the ascending aorta in relation to age and hypertension. Am J Cardiol 1970;25:411-5. [CrossRef]

21. Çetin M, Kocaman SA, Durakoğlugil ME, Erdoğan T, Uğurlu Y, Doğan $S$, et al. Independent determinants of ascending aortic dilatation in hypertensive patients: Smoking, endothelial dysfunction, and increased epicardial adipose tissue. Blood Press Monit 2012;17:223-30. [CrossRef]

22. Çanga A, Kocaman SA, Çetin M, Erdoğan T, Durakoğlugil ME, Çiçek $\mathrm{Y}$, et al. Increased epicardial adipose tissue thickness is correlated with ascending aortic diameter. Tohoku J Exp Med 2012;226:183-90.

23. Tomaro ML, Batlle AM. Bilirubin: Its role in cytoprotection against oxidative stress. Int J Biochem Cell Biol 2002;34:216-20. [CrossRef]

24. Glantzounis GK, Tsimoyiannis EC, Kappas AM, Galaris DA. Uric acid and oxidative stress. Curr Pharm Des 2005;11:4145-51. [CrossRef]

25. Arck PC, Overall R, Spatz K, Liezman C, Handjiski B, Klapp BF, et al. Towards a "free radical theory of graying": Melanocyte apoptosis in the aging human hair follicle is an indicator of oxidative stress induced tissue damage. FASEB J 2006;20:1567-9. [CrossRef]

26. Dobrin PB, Baker WH, Gley WC. Elastolytic and collagenolytic studies of arteries. Implications for the mechanical properties of aneurysms. Arch Surg 1984;119:405-9. [CrossRef]

27. Koch AE, Haines GK, Rizzo RJ, Radosevich JA, Pope RM, Robinson $\mathrm{PG}$, et al. Human abdominal aortic aneurysms. Immunophenotypic analysis suggesting an immune-mediated response. Am J Pathol 1990;137:1199-213.

28. Brophy CM, Reilly JM, Smith GJ, Tilson MD. The role of inflammation in nonspecific abdominal aortic aneurysm disease. Ann Vasc Surg 1991;5:229-33. [CrossRef]

29. Patel MI, Hardman DT, Fisher CM, Appleberg M. Current views on the pathogenesis of abdominal aortic aneurysms. J Am Coll Surg 1995;181:371-82.

30. Herron GS, Unemori E, Wong M, Rapp JH, Hibbs MH, Stoney RJ, et al. Connective tissue proteinases and inhibitors in abdominal aortic aneurysms. Involvement of the vasa vasorum in the pathogenesis of aortic aneurysms. Arterioscler Thromb 1991;11:1667-77. [CrossRef]

31. Freestone T, Turner RJ, Coady A, Higman DJ, Greenhalgh RM, Powell JT, et al. Inflammation and matrix metalloproteinases in the enlarging abdominal aortic aneurysm. Arterioscler Thromb Vasc Biol 1995;15:1145-51. [CrossRef]

32. Shah PK. Inflammation, metalloproteinases, and increased proteolysis: An emerging pathophysiological paradigm in aortic aneurysm. Circulation 1997;96:2115-7. [CrossRef]

33. Knox JB, Sukhova GK, Whittemore AD, Libby P. Evidence for altered balance between matrix metalloproteinases and their inhibitors in human aortic diseases. Circulation 1997;95:205-12. [CrossRef]

34. Siwik DA, Pagano PJ, Colucci WS. Oxidative stress regulates collagen synthesis and matrix metalloproteinase activity in cardiac fibroblasts. Am J Physiol Cell Physiol 2001;280:C53-60. [CrossRef]

35. Phillippi JA, Klyachko EA, Kenny JP 4th, Eskay MA, Gorman RC, Gleason TG, et al. Basal and oxidative stress-induced expression of metallothionein is decreased in ascending aortic aneurysms of bicuspid aortic valve patients. Circulation 2009;119:2498-506. [CrossRef] 